\title{
NIH head looks to the 'biomedical century'
}

Erika Check, Washington

The first time Elias Zerhouni heard from a US president was in 1985. Ronald Reagan was suffering from colon cancer and Zerhouni, a radiologist at Johns Hopkins University School of Medicine in Baltimore, Maryland, had just pioneered a new technique for differentiating between benign and cancerous growths. Reagan's doctors got in touch: would Zerhouni be willing to help treat the president using his new technique?

Zerhouni answered the president's call, just as he did again earlier this year when George W. Bush asked him to take over at the National Institutes of Health (NIH) in Bethesda, Maryland. Zerhouni was sworn in as the NIH's fifteenth director four months ago, and a photo of Reagan hangs behind his desk. Last week, he began to discuss his plans for the "biomedical century" - from the need for the NIH to sell itself, to how he will use the people skills he honed as an immigrant to advance the agency.

Zerhouni finds himself at the helm of the NIH just as the agency reaches the end of a five-year doubling of its budget, which should take next year's funding to $\$ 27.3$ billion. But the cash influx has brought problems. Some observers fear that funding will stagnate once the present increase is complete. Others worry that the agency's decentralized structure prevents it from funding cutting-edge research. Congress has appointed a committee to look at how the NIH is organized, and some panel members say that reorganizing the agency's 27 separate institutes into clusters would be more efficient (see Nature 418, 572; 2002).

\section{Speed trials}

Trumpeting the NIH's successes is one way to answer critics, says Zerhouni. He points out that the agency began investing in research into West Nile virus when it was first discovered in New York in 1999. Three years later, clinical trials of a candidate vaccine are under way. "Does that say this is an organization that's sclerosed and not flexible? I don't think so," he says.

This and other success stories could help convince Congress to keep on increasing $\mathrm{NIH}$ funding, but Zerhouni admits that the agency doesn't always do a good job of explaining why investment in biomedical research is useful. Asked how to make this case to the public, he pulls out a thick book of health statistics and traces the rise in deaths due to human immunodeficiency virus (HIV) through the 1980s to a peak in the mid-1990s. Without federal investment in the science behind retroviral therapies, he says, this line would have marched on and HIV would now kill at least eight times as many people in the United States as it

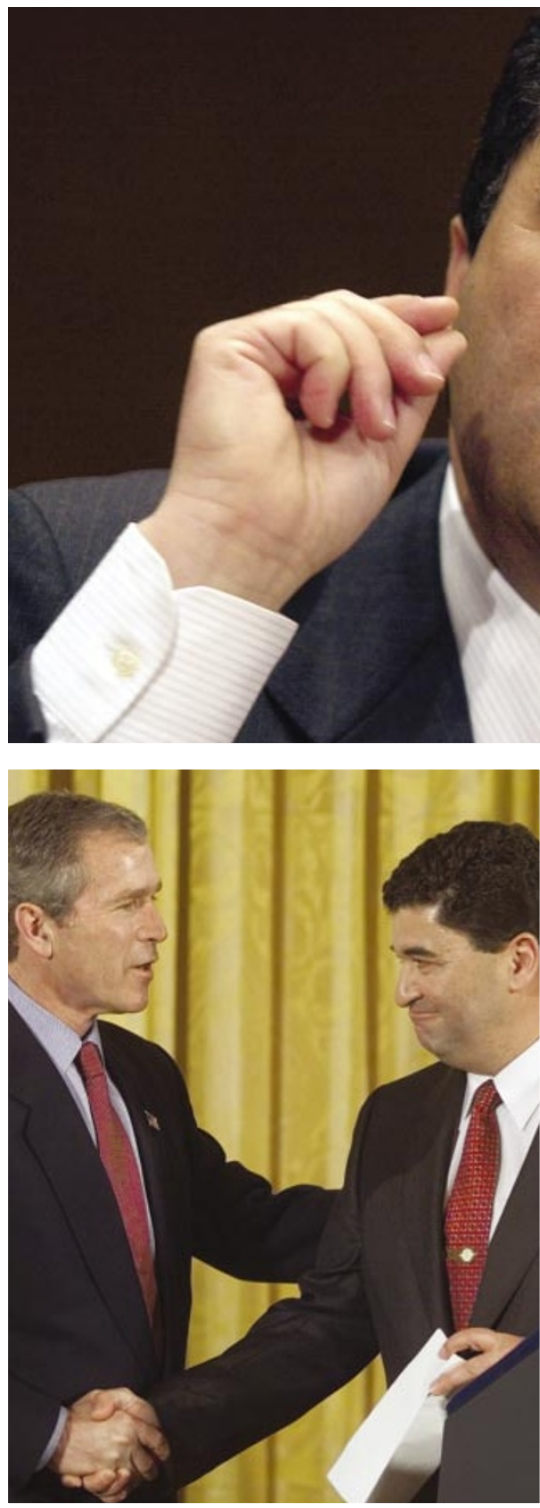

does. "If this is not getting a return on your money, I don't know what is," he says.

Nonetheless, Zerhouni realizes that the agency may have to change. New areas such as imaging, nanotechnology and proteomics require input from a range of disciplines. It's a process that he is familiar with, having assembled a multidisciplinary team of scientists to develop new imaging technologies when he was at Johns Hopkins - but not one that is suited to the NIH's structure. "The fundamental question is, can we execute strategies that are beyond the mission of one institute and yet are the responsibility of the entire NIH?" he asks.

Zerhouni also has a big recruitment job on his hands. Several institutes currently lack directors, including the National Institute of General Medical Sciences and the National Institute of Neurological Disorders and

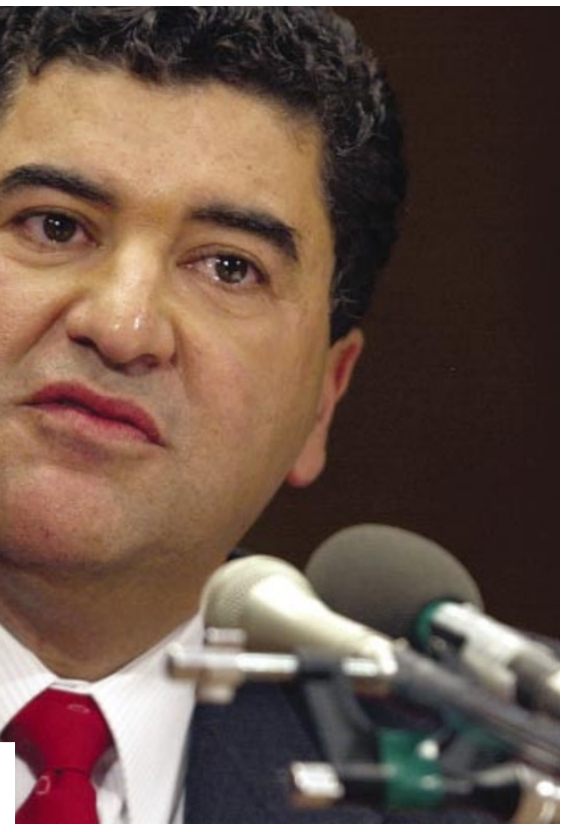

Appointed director by George W. Bush earlier this year (left), Elias Zerhouni wants to manage change at the NIH while publicizing its triumphs.

Stroke. He has already named new leaders at the National Institute of Mental Health and the National Institute on Alcohol Abuse and Alcoholism (see Nature 419, 240; 2002), and says that filling the remaining posts is one of his top priorities. "I take a lot of pains in recruiting people," Zerhouni says, adding that his job has been made somewhat easier by the recent increase in the NIH's budget. "Everybody feels that this is a historic moment in biomedical research."

It's easy to see how Zerhouni's calm, friendly manner could win the confidence of a prospective employee. Even as he ponders the big picture, he tries to make personal connections. Zerhouni arrived at his interview with Nature fresh from sharing a platform with the surgeon general, Richard Carmona. "I always look at people and say there must be a contact point," he says. He hadn't found one before with Carmona, but that day he had: Carmona grew up in Spanish Harlem, the New York City neighbourhood where Zerhouni's daughter, Yasmin, now teaches at a public school.

Zerhouni says he developed his skills at dealing with people as an entrepreneur during the early 1980s. He founded five companies, although he ended all connection with them on taking up his new post. Arriving as an immigrant from Algeria at the age of 24 also helped, as he had to create a new network of colleagues and friends. But his daughter keeps him humble, he says. "She tells me there's a greater need for teachers than there is for NIH directors." 